\title{
IMPACT OF PRETREATMENT OF WHEAT GRAIN USING INFRARED RADIATION ON FLOUR FALLING NUMBER
}

\author{
Mariusz Kania $^{\mathrm{a}}$, Agnieszka Sagan ${ }^{\mathrm{a}}$, Agata Blicharz-Kania ${ }^{\mathrm{a}}$, Agnieszka Starek ${ }^{\mathrm{a}}$, \\ Beata Ślaska-Grzywna ${ }^{\mathrm{a}}$, Andrzej Bochniak ${ }^{\mathrm{b}}$, Agnieszka Kubik-Komar ${ }^{\mathrm{b}}$, Marta Krajewska ${ }^{\mathrm{a}}$, \\ Beata Zdybel $^{\mathrm{a}}$ \\ ${ }^{\text {a }}$ Department of Biological Bases of Food and Feed Technology, \\ University of Life Sciences in Lublin \\ ${ }^{\mathrm{b}}$ Department of Mathematics and Informatics Usage, University of Life Sciences in Lublin \\ *Corresponding author: e-mail: agata.kania@up.lublin.pl
}

\begin{tabular}{|c|c|}
\hline ARTICLE INFO & ABSTRACT \\
\hline $\begin{array}{l}\text { Article history: } \\
\text { Received: August } 2016 \\
\text { Received in the revised form: } \\
\text { September } 2016 \\
\text { Accepted: September } 2016 \\
\end{array}$ & \multirow{2}{*}{$\begin{array}{l}\text { The aim of the research was to determine how time of infrared radia- } \\
\text { tion heating of grains influences the falling number of flour gained } \\
\text { from wheat variety Waluta and spelled wheat variety Schwabenkorn. } \\
\text { Moisture content was determined in the first stage of the study and it } \\
\text { was } 12 \% \pm 1 \% \text {. Then grain was moisturized to the moisture of: } 14,16 \\
\text { and } 18 \% \text {. Prepared material was subjected to infrared radiation heat- } \\
\text { ing at the temperature of } 150^{\circ} \mathrm{C} \text { for } 30,60,90 \text { and } 120 \text { seconds. The } \\
\text { heated material was sent to milling, and the falling number was de- } \\
\text { termined. It has been found that the infrared radiation heating of wheat } \\
\text { grains prior to milling significantly affects the falling number of flour, } \\
\text { which increases with the duration of heating grain. }\end{array}$} \\
\hline $\begin{array}{l}\text { Key words: } \\
\text { grain, infrared radiation, flour falling } \\
\text { number, wheat flour }\end{array}$ & \\
\hline
\end{tabular}

\section{Introduction}

Activity of amylolytic enzymes is an indicator of grain and flour quality. It enables correct preparation of mill mixtures of grains, from which flour with desired parameters is obtained (Pijanowski et al., 1997; Rogozińska et al., 2009). It also decides on the fermentation degree of dough and properties of crumb (Zarzycki et al., 2012). It is expressed as the falling number. The measurement consists in determination of the time necessary for falling down a mixer to the determined level in the bran suspension of flour in the special reactive sample.

The falling number is a value proportional to the bran viscosity and inversely proportionate to the amylolytic activity. The value of the falling number is used for classification of the grain quality and flour assessment based on which technological usefulness of raw material can be decided (Rachon et al., 2011). Wheat flour designed for bread baking should have amylolytic activity with a specific falling number within 200-280 s. Too high value of this index influences unfavourably the process of bread baking since bread obtained from flour with too low amylolytic activity has low volume, pale crust and brittle crumb. On the other hand, too low value of the falling number (high activity of amylolytic enzymes) favours excessive dextrinization of starch which may result in non-elasticity and 
Mariusz Kania et al.

viscosity of the bread crumb (Zarzycki et al., 2012; Zarzycki et al., 2014). Moreover, the wheat grain with the falling number lower than $150 \mathrm{~s}$ is in the state of great life activity and breaths intensely secreting water and heat. It may cause problems in the storage (Rut et al., 2007).

In flour production grain conditioning is very crucial and at the same time consuming. It consists in humidification and then seasoning in order to achieve even distribution of moisture in a grain. Thus, attempts to use infrared radiation are made. Thanks to infrared radiation the conditioning time may be shortened and activity of enzymes may be optimized, anti-nutrive factors can be deactivated and digestibility of nutrients can be increased (Andrejko et al., 2011; Rastogi, 2014). Moreover, attempts to combine such type of processing with vacuum impregnation in order to shorten the conditioning time and obtain desired milling parameters and properties of the product have been made (Rydzak et al., 2012; Rydzak and Andrejko, 2013). However, there is no information on the use of infrared radiation processing of spelt wheat. Presently, cultivation of this type of wheat is experiencing a renaissance. It is related to the development of organic farming, to which it is particularly adjusted, as well as with the increase of demand for traditional and organic products and appreciation of nutritious values of spell.

\section{Objective of the paper}

The objective of the paper was to determine the impact of initial processing of wheat grain with infrared radiation on the changes of the falling number for selected wheat varieties.

\section{Materials and methodology of research}

Scientific research consisted of regular wheat variety Waluta and spell wheat Schwabenkorn variety from a farm in Lubelskie Voivodeship. Before the research was initiated spell wheat was devoid of husk.

In case of grain collected from a storehouse moisture was determined according to the standard PN-EN ISO 712:2009. Moisture of material collected from the storehouse was at the level of $12 \% \pm 1 \%$. In order to determine the impact of infrared radiation heating time on the falling number, the wheat grain was moistened to the level of moisture of 14, 16 and $18 \%$. The amount of water needed for moistening of wheat was calculated from the following formula:

$$
M_{w}=\frac{x_{2}-x_{1}}{100-x_{2}} \cdot M_{N}
$$

where:

$M_{w}$ - the amount of water needed for moistening grain, (g)

$M_{N}$ - mass of moistened grain, (g)

$x_{1} \quad$ - initial moisture of wheat, (\%)

$x_{2}$ - demanded moisture of grain, (\%) 
Impact of pretreatment...

The next stage of research was thermal processing of grain carried out with the use of a laboratory device for processing with infrared radiation of grainy plant raw materials. Research material was subjected to infrared radiation within 30, 60, 90 and 120 seconds. Temperature on the surface of grain was $150^{\circ} \mathrm{C}$.

A sample of a grain of $300 \mathrm{~g}$ weight was directed to milling, which was carried out with the use of a laboratory mill Quadrumat Junior Brabender. After milling the falling number of flour was determined according to the standard PN-EN ISO 3093:2010.

All tests were carried out in three iterations. The obtained results were subjected to statistical analysis with the use of STATISTICA 10. Analysis of variance (ANOVA) was carried out and division into uniform groups was carried out with the use of Tukey's procedure with the significance level of $\alpha=0.05$.

\section{Results}

Results of measurements were presented in figures 1-4. Flour obtained from wheat spell grain of Schwabenkorn variety had higher values of the falling number in comparison to flour obtained from common wheat grain Waluta variety.

Heating time of grain with infrared rays proved to be a factor which determines the values of the falling number of flour (fig. 1-4). For all investigated samples, the falling number of flour increased along with extension of thermal processing of grain. Subjecting spell wheat Schwabenkorn variety to heating with infrared rays by $120 \mathrm{~s}$ allowed the increase of the falling number of flour in relation to the sample which was not subjected to heating by approximately 28-40 s in relation to the initial moisture of grain.

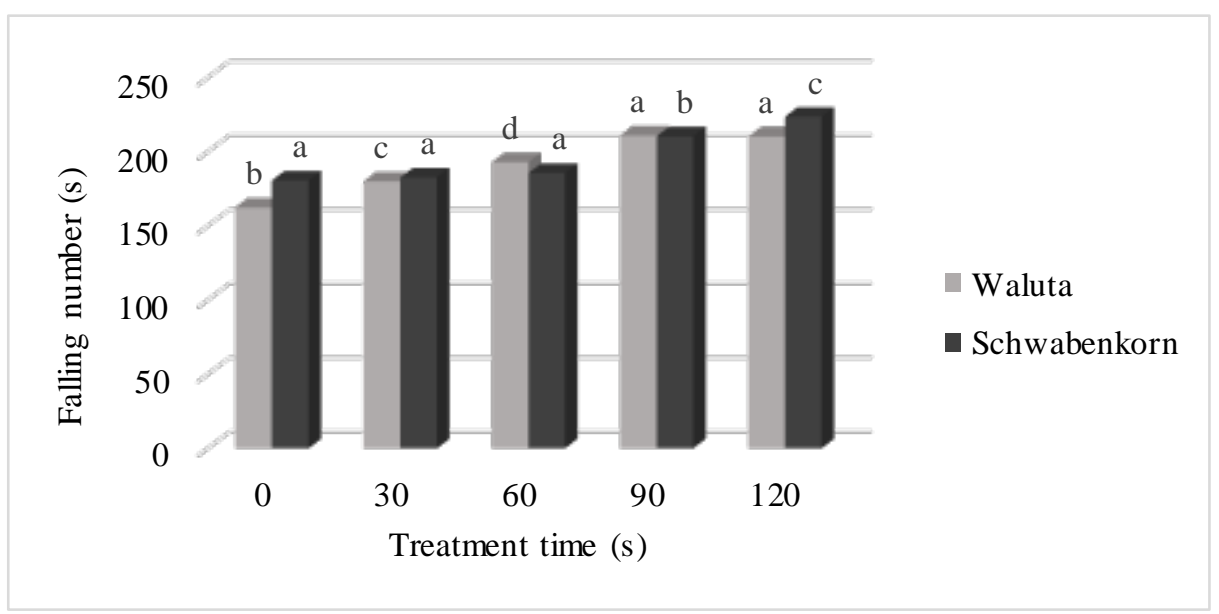

Figure 1. Changes in the falling number for flour obtained in the milling process of wheat grain in relation to duration of heating with infrared radiation of grain whose initial moisture was $12 \%$ 
Mariusz Kania et al.

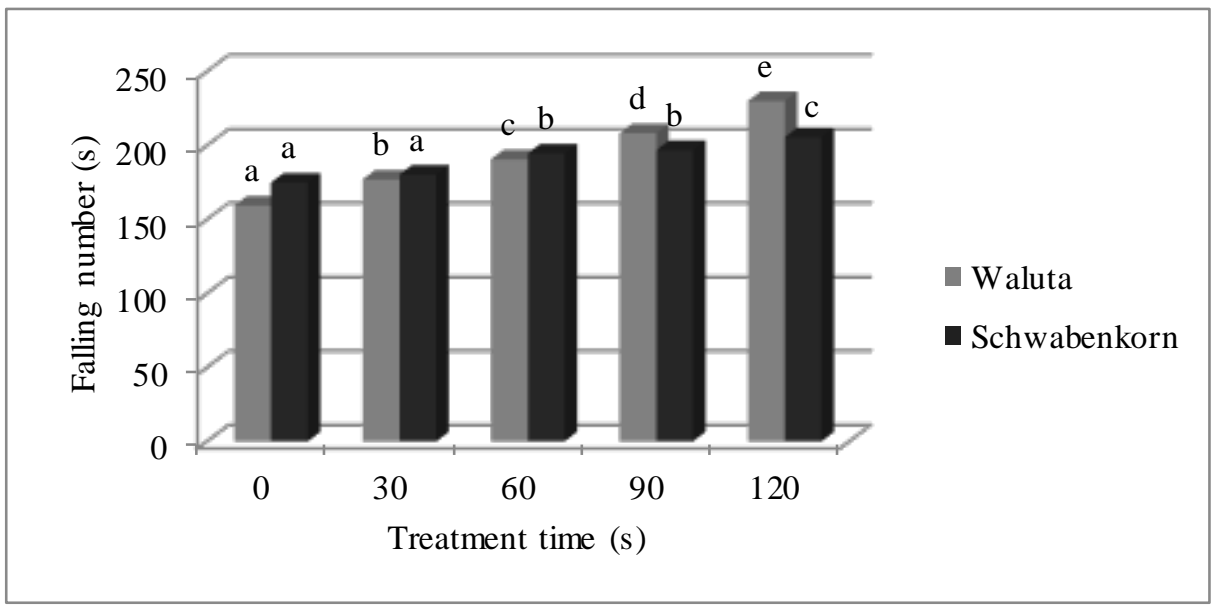

Figure 2. Changes in the falling number for flour obtained in the milling process of wheat grain in relation to duration of heating with infrared radiation of grain whose initial moisture was $14 \%$

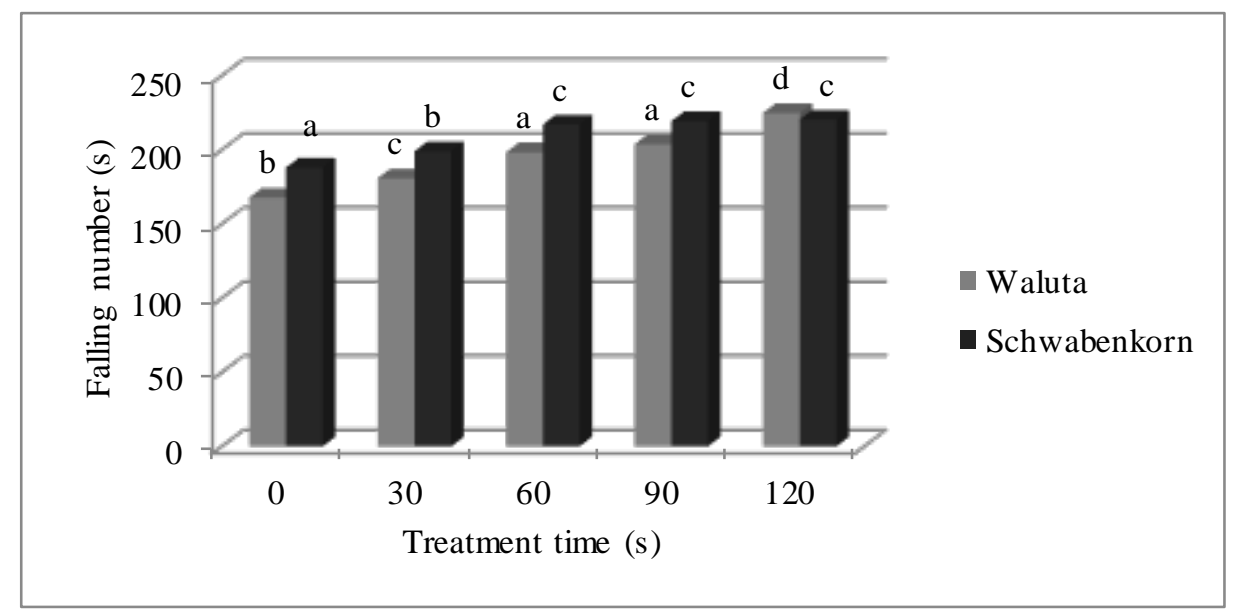

Figure 3. Changes in the falling number for flour obtained in the milling process of wheat grain in relation to duration of heating with infrared radiation of grain whose initial moisture was $16 \%$ 
Impact of pretreatment...

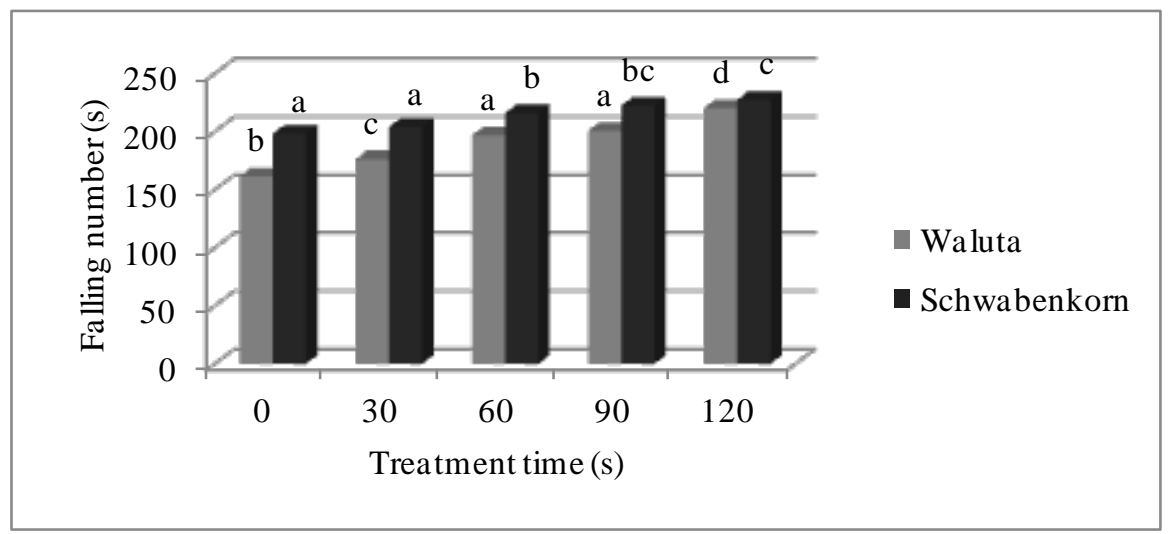

Figure 4. Changes in the falling number for flour obtained in the milling process of wheat grain in relation to duration of heating with infrared radiation of grain whose initial moisture was $18 \%$

This increase was even higher for flour obtained from Waluta variety wheat grain where $120 \mathrm{~s}$ treatment of grains with infrared rays resulted in the increase of the value of the falling number of flour by approximately 50-70 seconds in comparison to a control sample not subjected to heating. For flour obtained from common wheat (regardless the initial moisture of grain) and spell wheat with grain moisture of $16 \%$ significant changes of the falling number after 30 seconds of thermal treatment with infrared rays was reported. Dolińska et al. (2004) when she analysed the impact of heating of grain with microwave radiation on the flour properties she proved a significant impact of the falling number only after extension of the thermal treatment time from 120 to 180 seconds.

For analysis of the impact of grain moisture and heating time with infrared radiation on the falling number value a two-factor analysis of variance was applied. Based on the obtained results (table 1) it was found out that grain moisture and heating time and interaction of these variables significantly diversify the falling number.

Table 1.

Results of analysis of variance of the falling number in relation to wheat grain moisture and heating time, $p$-value $p$ test

\begin{tabular}{lcc}
\hline \multirow{2}{*}{ Factor } & \multicolumn{2}{c}{$p$} \\
\cline { 2 - 3 } & Waluta variety & Schwabenkorn variety \\
\hline Grain moisture (\%) & $<0.0001$ & $<0.0001$ \\
Heating time (s) & $<0.0001$ & 0.004 \\
Grain moisture $\cdot$ heating time & $<0.0001$ & $<0.0001$ \\
\hline
\end{tabular}

It was reported that along with the increase of moisture the value of the investigated property increased. In case of common wheat a statistically significant impact of moisture on the falling number was determined for grain subjected to initial treatment with infrared 
Mariusz Kania et al.

rays within 90 and 120 seconds (Table 2). Heating time had the biggest impact on the changes of the investigated property in case of using a grain with moisture of $14 \%$.

The values of the falling number of flour obtained from spell grain were more varied (Table 2). The impact of the level of moisture on the investigated property was reported for flour obtained from non-heated grain.

Statistical analysis demonstrated that the grain moisture was also a factor which significantly influenced the value of the falling number (table 1). Generally, it was observed that along with the increase of this parameter the value of the falling number grows. However, it should be noticed that in case of common wheat the biggest changes of the investigated property were reported for grain whose initial moisture was 14\% (table 2). The highest increase of the falling number took place after treatment with infrared rays of spell wheat grains with moisture of $12 \%$ within 90 seconds and it was $24.66 \mathrm{~s}$ in comparison to the grain heated within 60 seconds (table 2).

Table 2.

Results of Tukey's test for average values of the number in relation to moisture of wheat grain and heating time (various letters at average values mean statistically significant differences of results)

\begin{tabular}{|c|c|c|c|c|}
\hline \multirow{2}{*}{$\begin{array}{l}\text { Heating time } \\
\text { (s) }\end{array}$} & \multicolumn{4}{|c|}{ Moisture (\%) } \\
\hline & 12 & 14 & 16 & 18 \\
\hline \multicolumn{5}{|c|}{ Waluta variety } \\
\hline 0 & $162.33^{\mathrm{a}}$ & $159.33^{\mathrm{a}}$ & $167.67^{\mathrm{ab}}$ & $161.67^{\mathrm{a}}$ \\
\hline 30 & $180.00^{C}$ & $177.00 \mathrm{~b}^{\mathrm{c}}$ & $180.67^{\mathrm{c}}$ & $176.33^{\mathrm{bc}}$ \\
\hline 60 & $193.00^{\text {de }}$ & $190.67^{\mathrm{d}}$ & $198.33^{\text {def }}$ & $196.67^{\text {def }}$ \\
\hline 90 & $211.33^{\mathrm{hi}}$ & $208.33^{\text {gh }}$ & $203.67^{\text {fgh }}$ & $200.67^{\mathrm{efg}}$ \\
\hline 120 & $210.33^{\mathrm{h}}$ & $230.00^{\mathrm{k}}$ & $224,67^{\mathrm{jk}}$ & $220.33^{\mathrm{ij}}$ \\
\hline \multicolumn{5}{|c|}{ Schwabenkorn variety } \\
\hline 0 & $180.67^{\mathrm{ab}}$ & $175.00^{\mathrm{a}}$ & $188.00^{\mathrm{bcd}}$ & $198.33^{\mathrm{ef}}$ \\
\hline 30 & $182.67^{\mathrm{ab}}$ & $180.33^{\mathrm{ab}}$ & $199.00^{\mathrm{ef}}$ & $204.00^{\text {efg }}$ \\
\hline 60 & $185.67^{\mathrm{bc}}$ & $194.67^{\text {cde }}$ & $217.00^{\mathrm{hi}}$ & $216.00^{\text {hi }}$ \\
\hline 90 & $210.33^{\mathrm{gh}}$ & $197.00^{\text {def }}$ & $219.33^{\text {hij }}$ & $222.33^{\mathrm{ij}}$ \\
\hline 120 & $223.67^{\mathrm{ij}}$ & $205.67^{\mathrm{fg}}$ & $220.33^{\mathrm{ij}}$ & $227.67^{\mathrm{j}}$ \\
\hline
\end{tabular}

\section{Conclusion}

Based on the obtained results of research and their analysis the following conclusions have been made:

1. The falling number for flour obtained from spell wheat is at a higher level than in case of flour obtained from common wheat.

2. Initial treatment of wheat grain before milling by means of infrared radiation heating significantly influences the value of the falling number which increases along with extension of the heating time of grain.

3. Moisture of grain is a factor which significantly determines the changes of the investigated property. 
Impact of pretreatment...

4. The value of the falling number increases along with moisture. Initial treatment of grain with infrared radiation allows obtaining flour which had higher values of the falling number in comparison to flour obtained from non-heated grain. These values are within the scope which includes amylolytic activity for flour designed for bread baking.

\section{References}

Andrejko, D., Kania, M., Łatka, A., Rydzak, L. (2011). Wpływ obróbki cieplnej promieniami podczerwonymi na proces przemiału ziarna pszenicy odmiany Korynta. MOTROL Motoryzacja i Energetyka Rolnictwa, 13, 7-13.

Dolińska, R., Warchalewski, J.R., Gralik, J., Jankowski, T. (2004). Effect of $\gamma$-radiation and microwave heating of wheat grain on some starch properties in irradiated grain as well as in grain of the next generation crops. Food/Nahrung, 48(3), 195-200.

Pijanowski, E., Dłużewski, M., Dłużewska, A., Jarczyk, A. (1997). Ogólna technologia żywności.

WNT Warszawa. ISBN 8320405327

PN-EN ISO 712:2009 Ziarno zbóż i przetwory zbożowe - Oznaczanie wilgotności - Metoda odwoławcza.

PN-EN ISO 3093:2010 Pszenica, żyto i mąki z nich uzyskane, pszenica durum i semolina - Oznaczanie liczby opadania metodą Hagberga-Pertena.

Rachoń, L., Szumiło, G., Stankowski, S. (2011). Porównanie wybranych wskaźników wartości technologicznej pszenicy zwyczajnej (Triticum Aestivumssp. Vulgare), twardej (Triticum Durum) i orkiszowej (Triticum Aestivum ssp. Spelta). Fragmenta Agronomica, 28(4), 52-59.

Rastogi, N.K. (2014). Infrared heating of foods and its combination with electron beam processing. Electron Beam Pasteurization and Complementary Food Processing Technologies, 5, 61-82.

Rogozińska, I., Sadkiewicz, J., Pobereżny, J. (2009). Określenie aktywności enzymów amylolitycznych jako wskaźnik decydujący o jakości mąk żytnich. Inżynieria i Aparatura Chemiczna, 2, 122-124.

Rut, J., Szwedziak, A., Kuczek, B. (2007). Oznaczanie zawartości alfa-amylazy w ziarnie pszenicy zwyczajnej na podstawie liczby opadania. Postępy Techniki Przetwórstwa Spożywczego, 2, 23-25.

Rydzak, L., Andrejko, D., Masłowski, A., Hodara, K. (2012). Wpływ obróbki wstępnej ziarna pszenicy przed przemiałem z zastosowaniem impregnacji i mikronizacji na wyciąg mąki. Inżynieria Rolnicza, 3(138), 209-215.

Rydzak, L., Andrejko, D. (2013). Wpływ różnych sposobów przygotowania ziarna żyta do przemiału na wyciąg mąki i zawartość otrąb. Inżynieria Rolnicza, 1(141), 243-249.

Zarzycki, P., Sobota, A., Ciesielska, Ż. (2012). Wpływ czasu składowania na liczbę opadania oraz lepkość pozorną kleików mąk pszennych. Żywność Nauka Technologia Jakość, 6(85), 66-78.

Zarzycki, P., Kasprzak, M., Rzedzicki, Z., Sobota,„A., Sykut-Domańska, E. (2014). Właściwości reologiczne kleików z mąki pszennej jako wskaźnik oceny jej wartości wypiekowej. Żywność Nauka Technologia Jakość, 6(97), 50-66. 
Mariusz Kania et al.

\section{WPLYW OBRÓBKI WSTĘPNEJ ZIARNA PSZENICY PROMIENIAMI PODCZERWONYMI NA LICZBĘ OPADANIA MĄKI}

Streszczenie. Celem pracy było określenie wpływu czasu obróbki wstępnej ziarna promieniami podczerwonymi na zmiany liczby opadania dla mąki otrzymanej z pszenicy zwyczajnej odmiany Waluta oraz pszenicy orkisz odmiany Schwabenkorn. W pierwszym etapie badań oznaczono wilgotność ziarna, która kształtowała się na poziomie $12 \% \pm 1 \%$. Następnie ziarno dowilżono do wilgotności 14,16 i 18\%. Tak przygotowany materiał poddano obróbce cieplnej promieniami podczerwonymi w temp. $150^{\circ} \mathrm{C}$ w czasie $30,60,90$ i 120 s. Ogrzany materiał skierowano do przemiału, po czym oznaczono liczbę opadania. Stwierdzono, że ogrzewanie promieniami podczerwonymi ziarna pszenicy przed przemiałem istotnie wpływa na liczbę opadania, która wzrasta wraz z wydłużeniem czasu ogrzewania ziarna.

Słowa kluczowe: ziarno, promieniowanie podczerwone, liczba opadania, mąka pszenna 